This article was downloaded by: [Uppsala universitetsbibliotek]

On: 24 October 2013, At: 22:37

Publisher: Routledge

Informa Ltd Registered in England and Wales Registered Number: 1072954 Registered

office: Mortimer House, 37-41 Mortimer Street, London W1T 3J H, UK

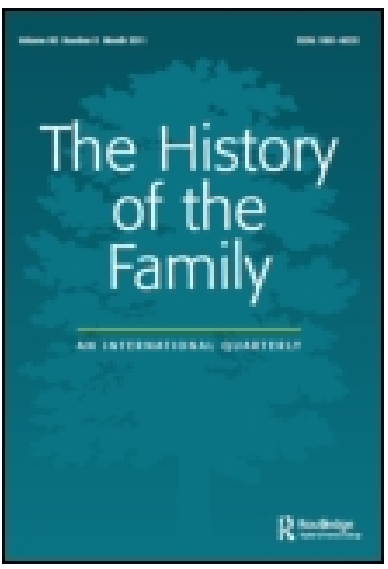

\title{
The History of the Family
}

Publication details, including instructions for authors and subscription information: http:// www.tandfonline.com/loi/ rhof20

\section{To depend on one's children or to depend on oneself: savings for old-age and children's impact on wealth}

\author{
Kristina Lilja ${ }^{a} \&$ Dan Bäcklund ${ }^{a}$ \\ a Department of Economic History, Uppsala University, Uppsala, \\ Sweden \\ Published online: 24 Oct 2013.
}

To cite this article: Kristina Lilja \& Dan Bäcklund (2013) To depend on one's children or to depend on oneself: savings for old-age and children's impact on wealth, The History of the Family, 18:4, 510-532, DOI: 10.1080/ 1081602X.2013.836458

To link to this article: http:// dx.doi.org/ 10.1080/ 1081602X.2013.836458

\section{PLEASE SCROLL DOWN FOR ARTICLE}

Taylor \& Francis makes every effort to ensure the accuracy of all the information (the "Content") contained in the publications on our platform. However, Taylor \& Francis, our agents, and our licensors make no representations or warranties whatsoever as to the accuracy, completeness, or suitability for any purpose of the Content. Any opinions and views expressed in this publication are the opinions and views of the authors, and are not the views of or endorsed by Taylor \& Francis. The accuracy of the Content should not be relied upon and should be independently verified with primary sources of information. Taylor and Francis shall not be liable for any losses, actions, claims, proceedings, demands, costs, expenses, damages, and other liabilities whatsoever or howsoever caused arising directly or indirectly in connection with, in relation to or arising out of the use of the Content.

This article may be used for research, teaching, and private study purposes. Any substantial or systematic reproduction, redistribution, reselling, loan, sub-licensing, systematic supply, or distribution in any form to anyone is expressly forbidden. Terms \& Conditions of access and use can be found at http://www.tandfonline.com/page/termsand-conditions 


\title{
To depend on one's children or to depend on oneself: savings for old-age and children's impact on wealth
}

\author{
Kristina Lilja* and Dan Bäcklund \\ Department of Economic History, Uppsala University, Uppsala, Sweden
}

(Received 5 April 2013; accepted 16 August 2013)

\begin{abstract}
How did workers make provisions for old age before the introduction of old age pensions? What was the relative importance of dependence on children and saving for old age respectively? This article concerns the transition from a traditional familybased system for economic support in old age to a more modern system. Regarding the nineteenth century, studies have shown that (a) savings generally were insufficient for full retirement, and that (b) families were dependent on children's incomes when the breadwinner became older. Little attention has been paid to the question of how the relative importance of these two alternatives changed during the century. This question is addressed here in a cross-sectional study of net wealth based on probate inventories for three Swedish towns in the 1820s and the 1900s.

The results show that in general the economic importance of children was larger among the lower socio-economic strata. They also reveal that net costs for having children increased between the investigated periods. This means that dependence on children became more expensive. Consequently, the economic importance of this alternative decreased. This may have been a strong motive for the fertility transition.

On the other hand, net wealth for workers increased at the end of the nineteenth century. Financial assets constituted a great part of the increase. Workers with children had less financial savings than those without children, showing that there was a conflict between the traditional and the modern systems for support in old age. However, still at the turn of the twentieth century funds were generally too small to allow an old worker to retire. These results indicate that neither the old, nor the modern systems, fully satisfied the need for support in old age. This may explain why several Western European countries introduced old age pensions at the beginning of the twentieth century.
\end{abstract}

Keywords: provision for old age; savings; old age; workers; master artisans; children; financial assets; urban Sweden; cross-sectional study; probate inventories

\section{Introduction}

In old age the capacity to carry out physically demanding tasks decreases rapidly. Consequently, before the introduction of social welfare programs and as long as manual labour was predominant, to be an old worker often meant experiencing difficulties in earning a living. One method to avoid these problems, highly advocated by nineteenth century Liberals, was saving for one's old age (Johnson, 1985, pp. 25-28, 176, 180, 193 201 and 218). However, saving requires an economic surplus, and, as long as wages were very low, workers as a rule had to rely on other solutions. One was to depend on one's children. Other alternatives were, for example, to continue working according to one's ability, to have lodgers or to rely on poor relief (Moring, 2008, pp. 105-117). Several different alternatives could of course be used simultaneously. In this article the focus is on

*Corresponding author. Email: kristina.lilja@ekhist.uu.se 
how the relative importance of the two alternatives, saving for old age and/or depending on one's children, changed during the nineteenth century. On a macro level the points of departure are the fertility transition and industrialization. The former indicates rising net costs for children (Becker, 1993, pp. 135-154; Bengtsson, 2006, pp. 132-135; Easterlin, 1998, pp. 95-112) and the latter increasing surpluses for savings. Consequently, the main hypothesis is that there was a shift, implying that the relative importance of children decreased, while that of savings increased.

Through a study of net wealth for urban groups that mainly supported themselves by incomes from own work, the relative economic importance of dependence on children and saving for old age respectively has been analyzed. Cross-sectional analysis was used on the same type of sources in the 1820s and the 1900s. For data on assets, debts and net wealth, probate inventories were used. To analyze dependence on children in old age, special emphasis was put on how adult children affected wealth. It has been shown that they had a more negative effect in the 1900s than in the 1820s. For unskilled workers the effect actually was nearly significantly positive in the 1820 s. The interpretation is that old workers' dependence on children became more expensive, and, as a consequence, a relatively less important way to provide for old age during the nineteenth century. Concerning saving for old age, the results reveal that in the 1900s, as well as in the 1820s, few workers could save enough for full retirement. However, net wealth for those 60 years and older increased between the two investigated periods, indicating that savings became relatively more important. This change in the relative importance between dependence on children and savings seems to have been neglected in most studies concerning nineteenth century family history. One important implication is that the concept of dependence on children in reality seems to have meant different things at the beginning and at the end of the nineteenth century. Probably this change has bearing upon the fertility transition, too. Furthermore, it deserves attention in analyses concerning the growing demand for old age pensions at the turn of the twentieth century.

\section{Previous research}

Adolescents' and adult children's positive effects on the family economy during the nineteenth and early twentieth centuries have been shown in many studies of family history. One, rather unreliable, indication of children's importance in urban areas is that old parents often lived together with their children. Alter (1996), in a study of Verviers, Belgium, in 1831, showed that more than $50 \%$ of parents even in their seventies were living together with one of their unmarried children. A study by Pérez-Fuentes Hernández and Arantza Pareja (1997) of pre-industrial Bilbao, Spain in 1825 pointed out a very high rate of cohabitation between parents and their children and, also, that this was not substantially affected by industrialization. Similar conditions seem to have prevailed in Sweden as is shown by Högman (1999, p. 104) in a study of Sundsvall.

Attendant questions of importance are if those who had children were better able to support themselves in old age than those who were childless, and if this changed during the nineteenth century. Alter, in the aforementioned study, gave a positive answer to the first question. He maintained that support from children explained why a greater proportion of married than unmarried people were able to pay taxes in old age (Alter, 1996). In contrast, Wall (2010, pp. 90-93), who studied English households 1600-2000, felt that it was impossible to draw any clear conclusions concerning the first question, as the economic contributions from children were in fact very variable. He did not discuss changes over time in these regards. 
It is also well known that even at the end of the nineteenth century, children's earnings were very important for worker family incomes when the parents aged. Early (1982, pp. 180-199) demonstrated for Lowell, Massachusetts, in 1870, that the larger the number of working children was, the higher the family income and material living standard were, too. In families where the breadwinners were unskilled, children's incomes were most important in order to stay above the poverty line. Robinson (1995, pp. 1-22) found for Indianapolis that sons (but not daughters) older than 10 years were important for the family income at the end of the nineteenth century. After the turn of the twentieth century daughters were important, too. The development was explained by expanding job opportunities for girls.

Haines (1979, pp. 289-356) revealed, in a study of the US and five European countries for the years 1889-90, that family income reached its peak when the male breadwinner was 50-59 years old, although the workers' own income was at its maximum already when they were 30-39 years. The explanation was mainly income contributions from the children, which were so great that also family savings were at their highest when the breadwinner was in his 50s. In families where the father was 60 or older, children provided $30-40 \%$ of the family income. However, using the same data set, Haines (1985) showed that only children who worked affected family savings positively, while children in school had a negative effect. Obviously the latter effect was stronger than the former, and as a consequence children in general affected family savings negatively through increasing consumption demands. His results stand in contrast to the abovementioned findings by Alter concerning the 1830s, and may indicate that net costs for children had increased and old workers' dependence on children had decreased during the intervening period.

On the other hand, the conditions for saving for old age had improved. As long as wages were low and uncertain, workers seldom had a surplus for long-term saving. A result of industrialization was that real wages rose in many Western European countries during the last decades of the nineteenth century (Allen, 2001, pp. 428-435). However, insecurity due to frequently recurring unemployment was great, and there were great fluctuations in wage rates as well. This situation meant a high level of income insecurity, especially for unskilled workers (Boyer, 2009), and great problems to earn a permanent surplus for savings and to carry through planned saving for old age (Johnson, 1984, pp. 206-216).

Despite this, the number of account holders in savings banks and savings funds, as well as the amounts deposited, grew rapidly during the second half of the century. Concerning Britain, Boyer (2009, pp. 62-72) shows that working class savings banks deposits were several times larger at the turn of the twentieth century than in 1830. A similar development occurred in other countries, for example Sweden, during the second half of the nineteenth century (Lilja, 2010, pp. 51-58). Did this mean that saving for old age became more common at the turn of the twentieth century?

According to the life cycle theory, individuals will try to smooth their consumption during their lifetime by saving surpluses during good years that can be used in old age. An underlying assumption in the theory is that there really are surpluses during periods and that the individuals are capable of calculating their own life expectancies (Modigliani \& Brumberg, 1954, p. 80). Both assumptions can be questioned, but the life cycle theory has been proven to be valid for the rich countries at least during the period after 1950 . Moreover, life cycle saving appears to have been widespread in Canada already at the end of the nineteenth century (Di Matteo, 1997, pp. 907-934). On the other hand, Johnson (1984, pp. 342-349; 1985) demonstrated that British workers were unable to save enough for retirement at the beginning of the twentieth century, mainly as a result of too small and 
unsafe economic surpluses. This, however, does not exclude that some workers accumulated savings for old age, and that this had become more common during the preceding decades.

As has been shown, there are indications that the importance of saving for old age increased towards the end of the nineteenth century and that parents' dependence on children decreased. This shift in instruments to insure income during old age has been studied in relation to fertility for the developing countries of today (for example Galasso, Gatti, \& Profeta, 2009; Jellal \& Wolff, 2002). Systematic studies regarding countries that were industrializing during the nineteenth century, using the same methods and types of sources for the time before and after the presumed shift, are necessary if one wants to analyze long-term changes in the relative importance of the two different alternatives.

\section{Aim, methods, and data}

This article concerns how Swedish urban groups that were living from their own work made provisions for old age. Cross-sectional studies of wealth, age and family structure in the 1820s and the 1900s were utilized, in order to observe changes over time. Between these two decades industrialization took off in Sweden (circa 1850) and the fertility transition started (circa 1880) (Schön, 2000, pp. 137-148 and 239-241). Another important difference was that real wages were considerably higher in the 1900s than in the 1820s (Söderberg, 2010, p. 464).

The aim has been to investigate the relative economic importance of the two alternatives: dependence on children and saving for old age, and if their respective significance was changing during the nineteenth century. There are no data on children's incomes and the costs of having children. Instead their impact on wealth is used as a proxy. Economically, children can be seen as some sort of insurance for old age with costs when they are young and yields when they become older. This means that the number of children in different ages should have had an impact on net wealth. If total yields were larger than total costs, those who had several children should have had more wealth in old age, compared to those who had few or no children. Of course, the outcome would have been the opposite, if costs were larger than yields. The other alternative, saving for old age, means that net wealth would have increased up to a maximum in late middle age and then decreased when assets were used for support in old age. Further, to really solve the problem of support in old age, maximum net wealth ought to have been significant enough for maintenance during the remaining lifetime. Consequently, the two alternatives to make provisions for old age ought to have affected net wealth differently during the life cycle.

The study has focused on three towns in Sweden: Eskilstuna, Falun and Uppsala. In order to delimit the investigation to groups who had their main income from their own work, master artisans and workers were studied in 1820-25 and corresponding groups skilled and unskilled workers - in 1900-05. ${ }^{1}$ By comparing two different but nearly related socio-economic groups dependent on their own work, the intention was to study how income differences influenced the respective importance of saving for old age and dependence on children. A complication is of course that some master artisans in the $1820 \mathrm{~s}$ had employees and thereby also made a business profit. As the average for middle sized Swedish towns at this time was approximately only 1.5 employees per master artisan and the productivity in handicrafts was low (Edgren, 1987, p. 72), profits were assumed to be small and used mainly for the maintenance of the master artisan's workshop. Furthermore, the few probated individuals with extremely large assets and/or debts were excluded, as this may indicate business activities of considerable proportions or perhaps large 
inheritances, which makes it more difficult to draw conclusions regarding those who mainly were living from their own work. ${ }^{2}$ Out of a total number of 284 probate inventories in 1820-25, 16 were excluded. For 1900-05 the corresponding figure was 21 out of 933 probate inventories (Table 3).

According to the Swedish law of 1734, it was compulsory to make probate inventories for all deceased who were married or widowed (Bringéus, 1977, pp. 62-70). Probate inventories constitute a kind of summation of one's life in economic terms and include a rather detailed description of assets (real estate, personal property, claims and financial savings) as well as debts by value and kind. By comparing inventories for deceased in different age groups, the development of the economic situation over the life cycle can be reconstructed (for example Di Matteo, 1997). In this study the method was used to reconstruct net wealth (assets minus debts) in different stages of life, in order to analyze savings for old age and children's impact on wealth.

Quantitative methods were used to study the relationship between family wealth, age and children. Probate inventories contain not only economic data, but also other kinds of information such as the marital status of the deceased, the number of living children and their ages, and often the professional affiliation of the deceased. Unfortunately, age data for the deceased were often missing, especially for 1900-05. Data from probates were supplemented with information from parish registers, but in many cases it was impossible to certainly identify and determine the age of the probated. As a consequence, two regression models were used, one with recorded age and one also including estimated age.

Swedish towns were rather small, especially in the 1820s. To attain a sufficient number of observations, probate inventories for six years and three towns were studied. Towns with rather different trade and industry were chosen, as the purpose was to study if there was a general pattern of providing for old age independent of the local economic structure. As older persons were somewhat overrepresented in the probate inventories, another advantage of the extended cross sections was that they gave numbers large enough to also draw conclusions regarding young and middle-aged master artisans and workers.

In practise, persons with no or few assets were seldom probated. This group was rather large, and as a consequence only a minority of the deceased were probated. As regards saving for old age, this falling off causes no problems as the fact that a person was not probated indicates that savings were very small, if there were any at all. Concerning children's impact on net wealth, it is more difficult to generalize from the study of probate inventories to those not probated. It is likely that children's income was more important for the poorest groups than for the relatively well-established workers who were probated. However, this also means that if children's economic impact became less positive, as assumed, between the 1820s and the 1900s, this probably occurred first among the betteroff workers dealt with in this study. Consequently, if there was a change in the relative importance of the two alternatives (having children or one's own savings) it ought to have left traces in the probate inventories.

Unmarried persons had much lower probate rates than married persons (Table 3). This may have been a result of fewer assets, as well as of the fact that it was not compulsory for this group to be probated. If the latter affected wealth for those who were probated, the effects can be controlled for in the regression analysis. Accordingly unmarried people were included in the study which had the advantage that it increased the group without children.

Another problem with using probate inventories is that some assets, for example personal property and real estate, may be undervalued. Montelius (1993, pp. 445-448) found for the town of Västerås, 1776-1806, that the value of personal property sold on 
auctions was $25 \%$ higher than the probated value. According to Isacson (1979, p. 139), studying the countryside in the first half of the nineteenth century, estate administrators revaluated personal property predestined for payments of debts by $33.3 \%$. He also considered real property as being greatly undervalued. Montelius did not mention anything about this, but he revaluated all assets by increasing their values by $25 \%$. In the present study, assuming that cash, claims, financial assets and liabilities always were noted in the inventories at their real amounts, only the values of personal property and real estate were raised by $25 \%$ for the 1820 s. For the 1900 s an investigation concerning Sweden's national wealth shows that assessed values for real estates in towns were $90 \%$ of market values, while personal property was substantially undervalued in the probate inventories (Sveriges nationalförmögenhet ...1912, pp. 114 and 302-303). Consequently, for this period the value of real estate was raised by $10 \%$, while the revaluation by $25 \%$ for personal property was retained. This means that we have used probated values to construct the value of total assets in the following way: For the 1820s total assets are the sum of $1.25 *$ real estate $+1.25 *$ personal property + cash + financial assets + claims. For the 1900 s total assets are the sum of $1.1 *$ real estate $+1.25 *$ personal property + cash + financial assets + claims. Concerning debts we have used the probated values of total debts in the inventories.

Many of the probated elderly were widowed. A related problem is that the reliability of probate inventories as a source regarding the standard of living of widows has been questioned. Moring (2007, pp. 233-249) states that the fact that widows had less probated wealth than married persons indicates that the legacies of the deceased men had been partially or totally divided. Her conclusion is primarily based on rural data during the eighteenth and nineteenth centuries, but is not supported by data from Stockholm, 16801750. That the legal regulations and practices were different in towns and in the countryside is confirmed by a study from urban Sweden in the nineteenth century showing that widows with children had more wealth than widows without children (Bäcklund \& Lilja, 2010). A likely interpretation is that the inheritance was not distributed between the heirs until the widow was deceased.

\section{The Swedish case}

In the 1820 s Sweden was still predominantly agrarian. Approximately three fourths of the male population was employed in the agricultural sector, which comprised nearly $40 \%$ of total GDP (Schön, 2000, p. 58). Consequently, at this time an overwhelming majority of Swedes were living in rural areas, while only $10 \%$ were living in towns (Nilsson, 1989, p. 129). However, an economic transformation was underway. Population growth was rapid, an agricultural revolution accompanied by proto-industrialization led to economic growth, markets expanded and the institutional settings of the economy were strongly remoulded during the following decades. This cleared the way for industrialization, which took off from the middle of the nineteenth century. As a result, economic growth accelerated, the industrial sector's share of GDP and total employment increased and urbanization received an impetus, too. In the 1900s the production volume of industry and agriculture was approximately the same, and the urbanization ratio was $30 \%$. At that time Sweden was becoming an industrial society (Nilsson, 1989, p. 129; Schön, 2000, pp. 53119, 137 and 228).

In general, the workers in the early factories lived under harsh economic and social conditions with low wages, a profound lack of living space, bad sanitary conditions and associated ill health. That said, there is nevertheless a consensus among Swedish 
researchers that workers' wages and living conditions were slowly improving already at the beginning of the industrialization period (Olsson, 1986, pp. 153-158). However, Swedish real wages were low in a European context, and there was hardly any surplus for saving. The wages started to rise rapidly at the end of the nineteenth century and doubled between 1880 and 1913 (Bagge et al., 1933, pp. 260-261). At the latter date they had surpassed British wages (O'Rourke \& Williamsson 1995, pp. 171-203). Estimates suggest that the share of food in workers' budgets fell from $65 \%$ in $1841-1860$, to $55 \%$ in 1881-1900 (Myrdal, 1933, pp. 118 and 138). The proportion fell further to $48 \%$ in $1913-$ 14 according to a cost of living investigation (CLI) that year (SOS. Levnadskostnaderna, 1921a, p. 44).

In the second half of the nineteenth century, new methods of saving such as savings banks, savings associations and life insurance were spreading (Lilja, 2004, pp. 46-58 and 165-174). Higher wages, greater surpluses after food costs had been paid and new, more accessible ways of saving all point towards increased savings among artisans and workers (Lilja, 2009). It therefore seems possible that, at the turn of the twentieth century, workers' own funds should to some extent have constituted an alternative or a complement to other methods to earn a living during old age.

During the late nineteenth century the conditions for economic dependence on children changed, too. At this time demands for compulsory schooling were raised (Nilsson \& Pettersson 1993, pp. 173-174). Furthermore, legislation concerning industrial welfare was implemented, and children and women were given priority in the law (Montgomery, 1951, pp. 148-162). At the same time the labour market for children decreased as industrial production became more mechanized (Olsson, 1980, pp. 117-146). These changes acted together to reduce children's wage-work and, consequently, their contributions to family incomes. In sum, it seems as if costs for children increased more than children's incomes during the late nineteenth century. This may explain why fertility decreased, as was already mentioned in the Introduction, and led to quickly falling birth rates in Swedish towns from the 1880s onwards (Nilsson, 1989, p. 176).

Considering these fundamental changes in living conditions during the nineteenth century, the main hypothesis here is that children's impact on wealth became more negative between the 1820s and the 1900s, while the importance of saving for old age increased during the same time.

\section{The towns of Eskilstuna, Falun and Uppsala, 1820-1900}

The three studied towns are all located in central Sweden. Eskilstuna had the smallest population in 1820. The number of inhabitants was just over 2000, while Falun and Uppsala at that time had twice as many inhabitants (Table 1). Population growth in Eskilstuna and Uppsala was rapid. In 1900, the former had nearly seven times and the

Table 1. Number of inhabitants in Eskilstuna, Falun and Uppsala 1820-1900, (Index base $1820=100)$.

\begin{tabular}{lcccrr}
\hline & 1820 & 1840 & 1860 & \multicolumn{1}{c}{1880} & \multicolumn{1}{c}{1900} \\
\hline Eskilstuna & $2010(100)$ & $3260(162)$ & $4628(230)$ & $8411(418)$ & $13663(680)$ \\
Falun & $4020(100)$ & $4161(104)$ & $4970(124)$ & $7305(182)$ & $9606(239)$ \\
Uppsala & $4463(100)$ & $5203(117)$ & $8459(190)$ & $15675(351)$ & $22855(512)$ \\
\hline
\end{tabular}

Source: Nilsson, 1992, pp. 9, 14, 16-17 and 21. 
latter five times as many inhabitants as in 1820. On the other hand Falun grew relatively slowly, and in 1900 it was the smallest of the three towns.

Uppsala had Sweden's first university and was the seat of the Swedish archbishop. In the early nineteenth century, the town still had several administrative functions. Unlike the other two towns, Uppsala had an academic and religious elite, which affected the town life in general (Lundh, 1977, pp. 437-457). Nearly half of the male population over 15 years old were master artisans and workers in 1820, and this increased to just over $50 \%$ in 1900 (Table 2). Manufacturing industry grew from 1870 onwards and became relatively diversified, including trades such as mechanical engineering, food, and consumption goods. These industries were mainly producing for the domestic market serving the region and the rapidly growing city of Stockholm (Ullenhag, 1984, pp. 18-22).

Falun, too, is one of Sweden's historically most well-known towns. Copper mining had been the main industry since the Middle Ages, and Falun was a very important mining town. However, in the early nineteenth century the town stagnated economically and demographically due to declining profitability in copper mining (Lilja, 2004, pp. 59-70). As a result employment in mining decreased, but still in 1820 half the male population were master artisans and workers (Table 2). The economic stagnation ceased during the last decades of the nineteenth century. An important cause was that Falun was connected to the Swedish railway system. Several manufacturing industries were established, and population doubled between 1860 and 1900 (Table 1). Despite this rapid industrialization at the end of the century, the proportion of master artisans and workers was somewhat lower in 1900 than in 1820 (Table 2).

At the beginning of the nineteenth century, the town of Eskilstuna was dominated by master artisans who specialized in wrought iron manufacture. Eskilstuna consisted of two parts, the Old Town and the Freetown: the latter had been founded in 1771 as an attempt to establish manufacturing production without craft guild coercion. A majority of the Freetown master artisans were smiths. There were also many master artisans in the Old Town (Hörsell, 1983; Ohlsson, 2001, pp. 15-31), and in 1820 artisans and workers together made up three fourths of the male population in Eskilstuna (Table 2). The two districts were merged in 1833. During the first half of the nineteenth century, differentiation between small and large workshops quickly increased as a result of protoindustrialization (Isacson \& Magnusson, 1987, pp. 95-108; Magnusson, 1988, pp. $103-$ 106). An extremely rapid industrialization took off from the middle of the century, and industries producing for example locomotives, rifles, knives and cutlery became very successful (Ohlsson, 2001, pp. 52-75). In 1900 the share of industrial workers out of the total population was abnormally high for Swedish conditions (Table 2). At that time Eskilstuna was Sweden's leading town in the iron and steel industry, and in Sweden it was known as 'the town of knives' (Ohlsson, 2001, p. 75).

Table 2. Share of the male population older than 15 years working as artisans and workers in Eskilstuna, Falun and Uppsala, 1820 and 1900, \%.

\begin{tabular}{lcc}
\hline & 1820 & 1900 \\
\hline Eskilstuna & 74 & 81 \\
Falun & 53 & 40 \\
Uppsala & 45 & 52 \\
\hline
\end{tabular}

Sources: DDB. Folkmängden formulär 320; BiSOS A. Befolkningsstatistik 1900, Del 3, pp. 6, 8 and 49; BiSOS C. Bergshandtering 1900, p. 17; BiSOS D. Fabriker och handtverk 1900, pp. 46-47, 70, 102 and 104. BiSOS

F. Handel 1900, p. 209. 


\section{Results and discussion}

This investigation was based on 268 probate inventories for $1820-25$ and 912 probate inventories for 1900-05 (Table 3). The probate rates were approximately 40\% in 1820-25 and 46\% in 1900-05. Master artisans had higher probate rates than workers in the 1820s, and skilled workers higher than unskilled in the 1900s. There were also great differences depending on marital status, married people having considerably higher probate rates than those who were unmarried or widowed. Table 3 further shows that the demographic situation had changed between the two periods. The median age of the probated was higher in the 1900s than in the 1820s as a result of decreasing mortality rates in the towns in the second half of the nineteenth century (Nilsson, 1989, p. 176). This decline was especially marked for infants and young children, and as a result the average number of living children per probated individual rose by $50 \%$. Another difference is that median wealth in constant prices was three times as high in 1900-05 as in 1820-25. This was probably a result of industrialization and rising real wages. Despite larger families, the surpluses for saving were larger at the turn of the twentieth century than in the 1820 s (Table 3 ).

\subsection{Wealth, age, and children 1820-25}

To study the covariance between age, children and wealth, multiple regression analysis was used, where the following variables from probate inventories and parish registers were included:

Dependent variable: $\sqrt{ }$ Assets $=\sqrt{ }$ Total assets $\left(\right.$ riksdaler riksgälds $/ \mathrm{SEK}^{3}$ )

Independent variables: $\sqrt{ }$ Debts $=\sqrt{ }$ Total debts $($ riksdaler riksgälds/SEK),

Age and $\mathrm{Age}^{2}=$ age and age ${ }^{2}$ of the probated (years),

$\sqrt{ }$ ch0-10 $=\sqrt{ }$ number of children aged $0-10$ years,

$\sqrt{ } \operatorname{ch} 11-20=\sqrt{ }$ number of children aged $11-20$ years,

$\sqrt{ } \operatorname{ch} 21-=\sqrt{ }$ number of adult children,

Controllers: $\quad$ Male $(1=$ male $)$,

Married $(1=$ married $)$,

Widowed (1 = widowed $)$,

Falun ( 1 = living in Falun),

Eskilstuna ( $1=$ living in Eskilstuna).

Table 3. The materials for 1820-25 and 1900-05 in comparison, wealth in constant prices 190004, SEK.

\begin{tabular}{lccccc}
\hline & \multicolumn{2}{c}{$1820-25$} & & \multicolumn{2}{c}{$1900-05$} \\
\cline { 2 - 3 } \cline { 5 - 6 } & Master artisans & Workers & & Skilled & Unskilled \\
\hline Total N & 140 & 144 & & 323 & 610 \\
N included in analysis & 126 & 142 & & 310 & 602 \\
Probate rate, unmarried, \% & 37 & 15 & & 19 & 28 \\
Probate rate, married, \% & 51 & 37 & & 78 & 61 \\
Probate rate, widowed, \% & 48 & 20 & & 28 & 36 \\
Median age, years & 51 & 1.3 & & 52 & 58 \\
Mean N children & 1.9 & 124 & & 610 & 391 \\
Median wealth, SEK & 197 & & &
\end{tabular}

Sources: ULA. Bouppteckningar, Död- och begravningsböcker, Husförhörslängder 1820-25 and 1900-05 for Eskilstuna, Falun and Uppsala. Note. Wealth is deflated according to the living cost index in Jörberg, 1972, p. 350 . 


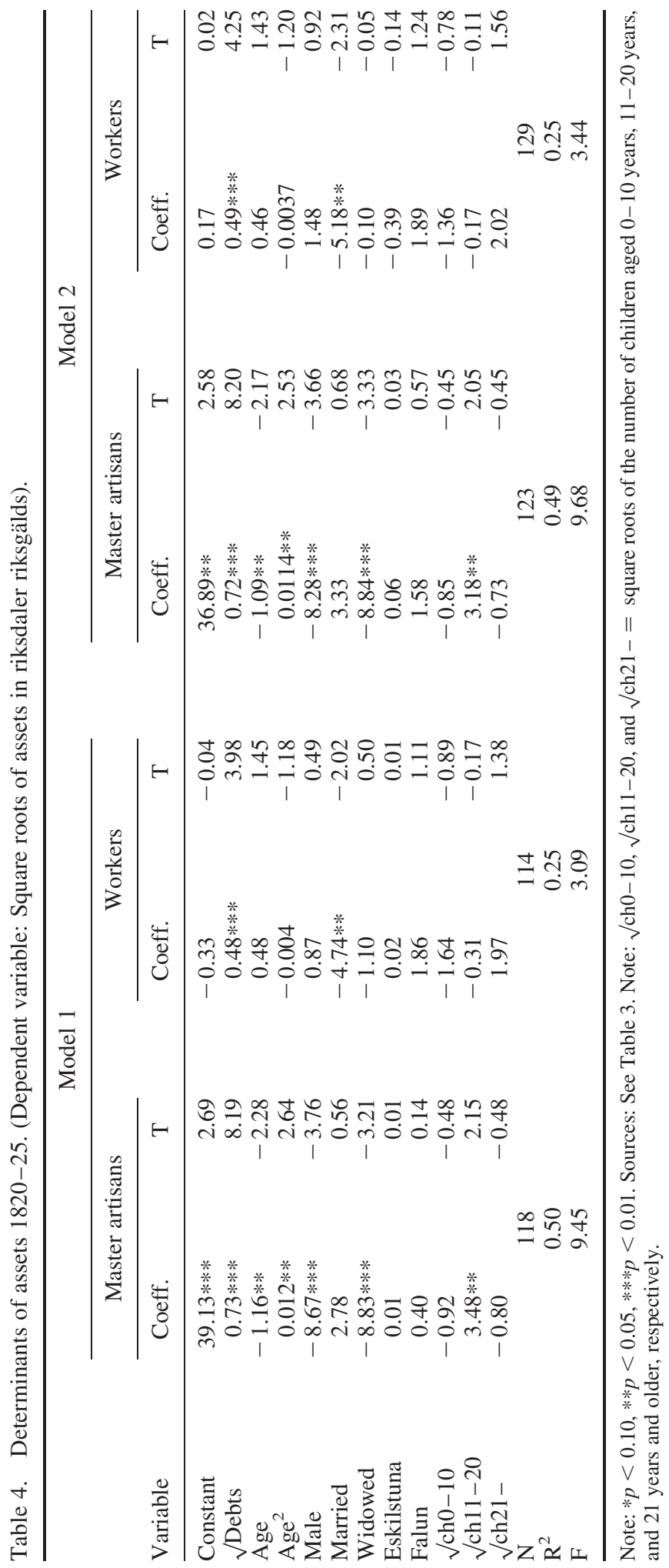


In the original version of this model, absolute values for net wealth and the number of children were used. When testing the model, it was found that outliers strongly affected the results. This was handled by using square roots, as the dispersion between large and small values for wealth was relatively modest and for children even less. Another advantage with this method was that the value zero could be handled without further transformations. A result of the method was that the sizes of the coefficients became difficult to interpret. However, it was not the sizes of the coefficients, but the question of whether they were significantly positive or negative, that were of interest in the analysis. Regarding wealth many probated master artisans and workers had net debts, and accordingly they would be excluded from the analysis when using square roots. As a consequence the model was modified in two ways. Square roots for assets were used as a dependent variable. Further, square roots for debts were added among the independent variables. This means that, strictly speaking, this is not an analysis of wealth, but instead of assets, taking debts into consideration.

According to the life cycle model, wealth should increase with age and decrease with age $^{2}$. Graphically this can be illustrated by an inverted U. Young children $(0-10$ years $)$ were supposed to have had a negative impact on wealth. As children grew older and could earn incomes, this negative effect should have decreased. ${ }^{4}$ The assumption is that adult children's impact on wealth showed the accumulated net costs for/net contributions from children. Considering debts, they should have had a positive effect on assets, as net wealth $=$ assets - debts. To exclude the influence of gender, marital status and local conditions, a number of dummy variables (Male, Married, Widowed, Falun, Eskilstuna) were used as controllers.

Data on age were missing for many of the probated, especially among workers. As a consequence, two models were used, one with recorded age variables (Model 1) and one including also estimated age (Model 2). This estimation was based on the ages of the children. An important point of departure was that people on average married just before their thirties (Edgren, 1987, pp. 180-182; Historical Statistics of Sweden, Part 1, 1969). Another was the ages of children among the probated with a recorded age. For probated without children, no estimation was possible.

In 1820-25 the age variables were statistically significant for master artisans' wealth, but not for workers' wealth (Table 4, Model 1 and 2). However, the regression coefficients show that master artisans' wealth decreased with age and increased with age ${ }^{2}$, meaning that very young as well as very old masters had relatively more wealth than those who were middle-aged. The explanation for this pattern is that master artisans were heavily indebted during the first years after the establishment of their businesses. Obviously the pattern is not in accordance with the life cycle model, which says that wealth ought to have been at its maximum just before old age. Other facts, too, indicate that very few master artisans were able to save for retirement at this time. ${ }^{5}$ Of those 63 probated masters with recorded age 50 years or more, 13 had net debts. For a majority of the remainder, wealth was small, and only $25(40 \%)$ had wealth corresponding to more than the yearly earnings (200 SEK) of a fully employed unskilled worker. ${ }^{6}$ Considering that probate rates were $50 \%$, this means that approximately $20 \%$ of the master artisans had that much wealth. For workers the proportion was $10-15 \% .^{7}$ These low percentages are hardly surprising given that productivity and wages were low before industrialization.

All master artisans and workers 50 years and older with wealth valued more than 200 SEK owned real estate, mainly houses. Nearly half of them were widows. By owning a house, an older person could decrease housing costs and possibly get income from letting. This can be seen as a method of saving for old age that seems to have been relatively 
common in Swedish towns at this time. It did not provide enough earnings for an old person to retire from work, but it somewhat lessened the need for income. The method was used chiefly by master artisans, but also to a lesser extent by worker households. In the town of Falun, however, owning real estate was very common also among mine workers, as they by tradition were given an opportunity to buy a house in the neighbourhood of the mine (Lilja, 2004, pp. 85 and 160-162). Differences between the towns were great, however. Among workers 50 years and older, the proportion with real estate was $80 \%$ in the town of Falun and 30\% in the town of Uppsala. No probated worker of that age in Eskilstuna owned real estate.

According to Table 4, the number of children aged 11-20 had a significant positive impact on master artisans' wealth. A comparison of probated masters aged 41-60, with and without children 11-20 respectively, reveals that debts were approximately the same for both groups, but that the former had nearly $50 \%$ more assets than the latter. This indicates that children's work was very important for family wealth. Families with adolescents had more real estate, but not more personal property. Thus, it seems as if adolescents took part in parents' efforts to pay off debts on real estate. This outcome is reminiscent of the previously mentioned studies dealing with workers in the second half of the nineteenth century by for example Early (1982), Haines (1979) and Robinson (1995) that indicated that the number of working children was important for family income.

It has been suggested that master artisans used sons instead of employees, although relatively few of them seem to have been apprentices (Edgren, 1987, p. 152; Hörsell, 1983, p. 95). Master artisans had large households including not only the family, but often also journeymen and apprentices. This means that household work by children probably was important. It is tempting to believe that children, primarily daughters, often accomplished part of this work and thereby helped to improve the economic situation of the family.

Did this mean that old artisans with children were economically better off than their childless counterparts? Not at all! As can be seen in Table 4 the number of adult children was not significant for wealth, and most probated persons older than 60 years only had adult children, if any. This can be interpreted as indicating that children had a positive influence on wealth as adolescents, but not after they had left home. This, however, does not exclude those adult children who, when necessary, helped their old parents to avoid the poverty trap (Edgren, 1982, pp. 52-53).

For workers, in contrast to master artisans, the number of children in different ages did not significantly influence wealth when only probated persons with age recorded were considered (Table 4, Model 1). There was, however, a tendency that adult children (21-) had a positive impact on wealth. When expanding the population to include also probated workers with estimated age, the variable became nearly significant (Model 2, $T=1.56$, $p=0.12$ ). This is in accordance with Alter's findings regarding children's influence on family income and wealth in Belgium in the 1830s.

Looking deeper into data from the Swedish towns, it appears that workers with adult children owned real estate much more often than those without children. ${ }^{8}$ In fact, the number of adult children had a significant positive effect on total assets. However, they had no similar effect on debts (Table A, Appendix). This stands in stark contrast to the circumstances when children were younger. In those ages the number of children only had a significant influence on debts. From this one may conclude that workers incurred debts when children were young and adolescents. Probably some of the loans were used for buying real estate. In fact workers most often bought real estate in their late forties or in their early fifties, i.e. in the ages when they also had adolescents. At that age workers normally already had passed their maximum earning capacity. ${ }^{9}$ It seems probable that 
children in their upper teens supported their parents to pay off debts and to keep assets for old age. As a consequence workers with adult children had significantly more assets, but not more debts, than childless workers of similar age. It would thus seem that young children resulted in net costs, but that older children made it easier for parents to buy and pay for real estate, which in turn meant significantly more assets in old age. This reciprocity between parents and children could be seen by the former as a sort of 'insurance saving through children'.

\subsection{Wealth, age, and children 1900-05}

To repeat, the fundamental hypothesis for this investigation was that between the $1820 \mathrm{~s}$ and the 1900s the importance of dependence on children should decline, while the importance of saving for old age should increase.

The results for 1900-05 do not give much support for the second half of this hypothesis, at least concerning life cycle saving. According to Table 6, Age and $\mathrm{Age}^{2}$ were not significant determinants of wealth either for skilled or unskilled workers. This indicates that life cycle saving was uncommon among Swedish workers even at the turn of the twentieth century. The result is in accordance with what Johnson (1985) found for Britain.

Most workers were in fact unable to save enough for retirement. Median wealth was 882 SEK for skilled workers aged 61-70 and 452 SEK for unskilled workers at that age. In constant prices this was nearly four times as much as workers of a corresponding age had in the 1820s (Table 5). Consequently, savings had increased considerably during the second half of the nineteenth century. Mean values for real estate were remarkably higher in the 1900s, but at the same time house-owning was more concentrated than in the 1820s. This means that relatively few had their wealth mainly in real estate at the turn of the twentieth century, and that such assets were relatively unimportant for the increase in median wealth between the 1820s and the 1900s. Of much greater importance was the growth of financial assets, as this was widely spread among workers. In fact these assets made up more than half of the increase in total assets for workers between the two investigated periods.

Table 5. Assets, debts and net wealth for probated 61-70 years old (recorded age), 1820-25 and 1900-05. Constant prices 1900-04, SEK.

\begin{tabular}{lccrrrr}
\hline & \multicolumn{2}{c}{$1820-25$} & & \multicolumn{2}{c}{$1900-05$} \\
\cline { 2 - 3 } \cline { 5 - 6 } & Master artisans & Workers & & Skilled & Unskilled \\
\hline $\mathrm{N}$ & 15 & 22 & & 48 & 87 \\
Real estate, mean & 434 & 277 & & 1229 & 485 \\
Financial assets, mean & 0 & 0 & 809 & 555 \\
Claims, mean & 149 & 170 & 50 & 58 \\
Personal property (including cash), mean & 298 & 154 & 332 & 248 \\
Total assets, mean & 881 & 601 & 2420 & 1346 \\
Debts, mean & 263 & 32 & 589 & 262 \\
Wealth, mean & 618 & 571 & 1831 & 1083 \\
Wealth, median & 128 & 170 & 882 & 452 \\
Percentage with wealth for five years & 27 & 23 & & 52 & 38 \\
$\quad$ or more at a subsistence level & & & & \\
\hline
\end{tabular}

Sources: See Table 3. Note. Deflated according to the living cost index in Jörberg, 1972, p. 350. 


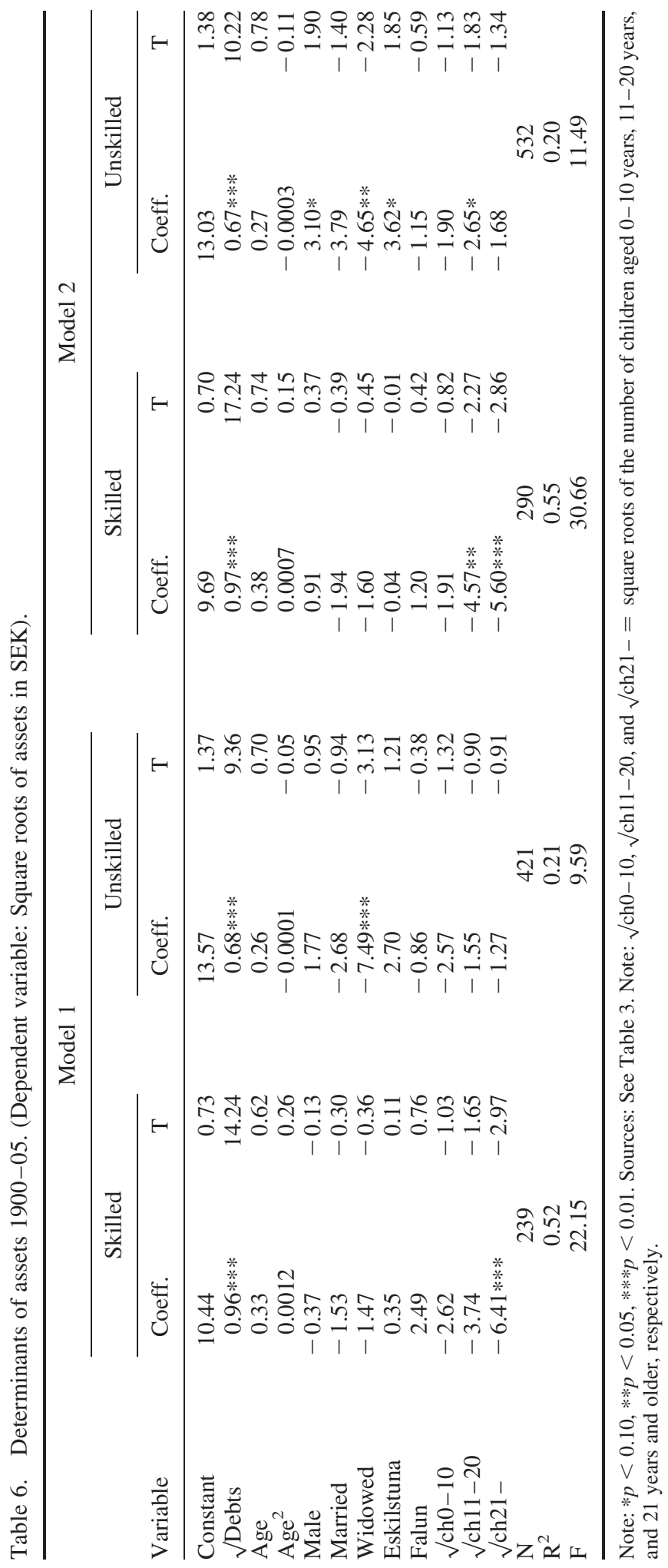


Wages had increased too, however, and for skilled workers median wealth corresponded to approximately the annual earnings of a male worker in manufacturing in 1900, while those who were unskilled had half as much. ${ }^{10}$ It thus seems more relevant to compare probated wealth with some sort of subsistence level. An investigation of poor relief for 1907 showed that full support for a single man on average amounted to 156 SEK per year (Elmér, 1960, p. 262). This means that median probated wealth for unskilled workers aged 61-70 was enough for at most three years of full support at a subsistence level. The amount lasted half that time for a married couple. The situation was of course even worse for the approximately $50 \%$ of workers who were not probated. Nevertheless, some of those who were probated had wealth enough to support themselves for a longer time. Approximately 50\% of the skilled workers and nearly $40 \%$ of the unskilled workers had wealth corresponding to at least five years of full support for one person (Table 5). In the 1820 s only $25 \%$ had that much wealth. This means that the buffer against loss of income was significantly greater in the 1900s, but that it still was just a buffer and not enough for maintenance in old age. ${ }^{11}$ Only one fourth had wealth enough for 10 years of living at the subsistence level defined by poor-relief at this time. Considering that this was the norm for poor-relief, it must have been an absolute minimum for subsistence. Taking probate rates into consideration, this means that at most one worker out of eight was able to fully provide for old age through savings. ${ }^{12}$ Consequently, even at the turn of the twentieth century, the majority of workers had to work for their living even in old age. This is confirmed by the census of 1910 showing that $57 \%$ of men 65 years and above in urban areas in Sweden were recorded with an occupation (SOS Folkräkningarna 1910). Furthermore, an investigation concerning the elderly in Sweden in 1907 shows that in towns $42 \%$ of those 70 years and older had to rely exclusively on incomes from their own work and/or from savings. Among those who had support, the most common was private allowances. In this way $15 \%$ were fully provided for, and another $26 \%$ partially. ${ }^{13}$ There are good reasons to assume that it was mainly adult children that provided private support.

What were the costs for this dependence on children? Both models in Table 6 reveal that children affected wealth negatively in 1900-05. This is in accordance with the results in Haines (1985). A comparison with 1820-25 (Table 4) shows a more negative impact on wealth in 1900-05 for children in all ages, though all coefficients are not significant. This holds true for skilled workers, as well as for unskilled workers. It is to be noted that all significant coefficients for children in 1820-25 are positive, while they are negative in 1900-05. The interpretation is that this reversal reflects rising net costs for children during the intermediate period.

The effects on wealth of having children are more clearly demonstrated in Table 7. Young children (0-10) did not significantly affect wealth either in the 1820 s or the 1900 s. On the other hand, when children became older (11 and up) the effects were apparent. Adolescents had a negative impact on wealth for skilled as well as unskilled workers in the

Table 7. Children's impact on wealth in the 1820s and the 1900s.

\begin{tabular}{|c|c|c|c|c|}
\hline & \multicolumn{2}{|c|}{ Master artisans/skilled workers } & \multicolumn{2}{|c|}{ Workers/unskilled workers } \\
\hline & $1820-25$ & $1900-05$ & $1820-25$ & $1900-05$ \\
\hline $0-10$ years & 0 & 0 & 0 & 0 \\
\hline $11-20$ years & + & - & 0 & - \\
\hline $21-$ years & 0 & - & $(+)$ & 0 \\
\hline
\end{tabular}

Note: Sign within brackets $=$ nearly significant. Sources: Tables 4 and 6, Models 2. 
1900s, while the effects were positive and not significant respectively in the 1820s. Adult children affected skilled workers' wealth negatively in the 1900s, but had no effect on master artisans' wealth in the 1820s. For unskilled workers, children of that age had no influence on wealth in the 1900s, while there was an almost significant positive effect on wealth in the 1820s. The conclusion is that children at the turn of the twentieth century had become an expensive solution for securing support in old age. It seems probable that this increase in net costs for children accelerated the fertility transition at the end of the nineteenth century. It is also worth noting the similarities between the 1820s and the 1900s concerning adult children's relatively more positive (less negative) impact on wealth for unskilled groups. This points towards an earlier fertility transition for skilled compared to unskilled workers, something that has been suggested for Britain by for example Haines (1979) and Barnes and Guinnane (2012). ${ }^{14}$

Another important observation is that data presented earlier, showing that children supported their aged parents, do not contradict the results in Table 6. Life expectancy was low still at the turn of the twentieth century ${ }^{15}$, which means that relatively few parents could expect to become 70 years old and fewer still to live long enough to fully get back accumulated net costs for children. ${ }^{16}$

The fact that effects on wealth were related to having adolescent and adult children makes one think of children's more restricted possibilities to work for wages as a consequence of child labour legislation, the shrinking market for child labour, and the increasing demands for compulsory schooling at the end of the nineteenth century, mentioned earlier in this article. The difference between skilled and unskilled workers may indicate that the former invested more in their children's education than the latter. Perhaps the main reason was that skilled workers had more economic resources and could afford to send their adolescents to continued education (for example vocational education), while children with unskilled parents more often were obliged to work for their living when they left the compulsory school.

By using data from the CLI in 1913-14, the results in Table 6 concerning children's impact on wealth could be checked against more precise information about the effects of children on household income and savings. The investigation comprised households with husband and wife and their children (Sveriges officiella statistik (SOS), 1921a, p. 22). It showed that few children younger than 14 had incomes. According to Table 8, worker families with children aged 12 or younger saved less than corresponding families without children, although the former had somewhat higher household incomes. This was more than counterbalanced, however, by the fact that also household expenses for those with

Table 8. Working class households (husband and wife) in 1913-14 with and without children. Breadwinners in different age groups. Medians, SEK.

\begin{tabular}{lccccc}
\hline & \multicolumn{2}{c}{ Age 30-39 } & & \multicolumn{2}{c}{ Age 40-60* } \\
\cline { 2 - 3 } \cline { 5 - 6 } Breadwinner & $\begin{array}{c}\text { Without } \\
\text { children }\end{array}$ & $\begin{array}{c}\text { With children } \\
0-12\end{array}$ & & $\begin{array}{l}\text { Without } \\
\text { children }\end{array}$ & $\begin{array}{c}\text { With } \\
\text { children 14- }\end{array}$ \\
\hline $\mathrm{N}$ & 29 & 301 & & 18 & 34 \\
Breadwinner income & 1393 & 1498 & & 1429 & 1513 \\
Household income & 1569 & 1675 & & 1633 & 1996 \\
Household expenses & 1501 & 1626 & & 1562 & 1922 \\
Total savings & 94 & 55 & & 79 & 87 \\
\hline
\end{tabular}

Note: * Only breadwinners without children younger than 14 are included. Source: SOS. Levnadskostnaderna (1921b). 
children were higher than for those without children. Concerning breadwinners aged $40-$ 60, families with children 14 years or older had considerably higher household incomes than families without children. The difference was primarily made up of children's contributions to household income, but as household expenses were higher, too, total savings were approximately the same for both groups.

This confirms that children could begin to earn some income when they left school and that this successively decreased the family's net costs for having children. As a consequence workers with children 14 years and older could save approximately as much as those without children. Nevertheless, the economic contributions from adolescents and grown up children do not seem to have compensated for the extra costs they had caused the family during childhood. This means that total costs for children were higher than their total economic contributions to the family income, which is in accordance with the differences in wealth shown by the probate inventories.

A new feature in 1900-05 was that more than 60\% of the workers had financial assets, for example savings banks accounts, life insurance and assets in Hundramannaföreningar and Tusenmannaföreningar (both kinds of Friendly societies). The percentage with such assets was a little higher for skilled than for unskilled workers. Financial assets were most common among skilled workers and constituted approximately one third of their total assets (Table 5).

At the beginning of the twentieth century, an additional alternative for financial saving was established - endowment assurances. These could be used as funds for old age and quickly became very popular among workers. The number of insurance policies in Sweden increased from 168,000 in 1900 to 855,000 in 1914 (Bergander, 1967, p. 367). The cost of living investigation (CLI) in 1913-14 showed that more than two workers out of three were saving in endowment assurances or life insurance (SOS. Levnadskostnaderna, 1921b). The amounts saved were on average small, circa 40-50 SEK per year, but endowment assurances still made up approximately half of total savings that year. This indicates that saving for old age was prioritized among workers, although the capacity to save enough was still very limited.

Was one consequence of high costs for children that workers without children utilized the new small saver institutions more intensely and had larger financial assets than workers with children? According to probate inventories from 1900-05, the answer is yes. Old workers with large families had significantly less financial assets than those with small families, and, among unskilled workers with children, approximately 50\% had no financial assets at all (Table 9). ${ }^{17}$ It is tempting to believe that large families had more real estate and personal property than small families and that this can in part explain the differences in financial assets. However, on closer inspection it turns out that medians for real estate and personal property were approximately the same irrespective of family size, although they were higher for skilled than for unskilled workers. Consequently, it seems as if financial savings for old age were accumulated out of the surplus that remained when the most basic needs of food, housing, clothes, furniture and so on were satisfied.

A great advantage with financial assets was that they were variable and could be converted into cash when needed. This means that they were especially suitable for saving for old age. As Table 9 shows, work skills (resulting in a higher income level) strongly affected the capacity for financial saving. In addition to this, the number of dependents was very important as well. In contrast to the situation in the 1820 s, there was obviously a clash of interest between having children and saving for old age at the turn of the twentieth century. That this opposition existed was confirmed by CLI data regarding yearly savings in endowment assurances for 1913-14, showing that workers who had children saved less 
Table 9. Probated workers (skilled and unskilled respectively) older than 60 (including those with estimated age), number of children and financial assets 1900-05, SEK.

\begin{tabular}{llrrrrrr}
\hline & \multicolumn{3}{c}{ Skilled } & & \multicolumn{3}{c}{ Unskilled } \\
\cline { 2 - 3 } Number of children & $\mathrm{N}$ & Mean & Median & & $\mathrm{N}$ & Mean & Median \\
\hline 0 & 15 & 1504 & 1347 & & 52 & 873 & 201 \\
$1-2$ & 36 & 896 & 229 & & 74 & 434 & 0 \\
$3-$ & 54 & 728 & 116 & & 101 & 297 & 10 \\
\hline
\end{tabular}

Sources: See Table 3.

than those without children. This difference was valid for all income groups and was greater the lower income was. ${ }^{18}$

\section{Conclusions}

This article deals with changes during the nineteenth century in two alternatives for making provisions for old age, dependence on children and one's own savings. The analysis has been based on cross-sectional studies of net wealth according to probate inventories for urban workers in three Swedish towns in the 1820s and the 1900s. Special emphasis was put on adult children's impact on wealth and on the size of net wealth for the elderly. By utilizing the same method for both periods, it was possible to discern that the relative importance of saving for old age increased, while that of depending on one's children decreased during the nineteenth century.

In the 1820 s adolescents positively influenced master artisans' wealth, probably by working in the household and the workshop. Adult children, however, had no significant impact on masters' wealth, indicating that the accumulated costs for having children were approximately equivalent to children's accumulated contributions to family income. Thus, children in general functioned as an 'old age insurance' at zero costs. This forms a contrast to workers for whom adult children had a nearly significant positive impact on wealth, indicating what can be seen as an 'insurance saving through children'. On closer examination, it became apparent that workers incurred debts and bought real estate when children were young or adolescents. As children grew older, they probably helped their parents to repay loans, and as a consequence workers with adult children had more assets, but not more debts, than workers of the same age without children.

The difference between master artisans and workers leads to the conclusion that adult children were of greater economic importance for groups with very limited assets. This seems to hold true in the 1900s as well as in the 1820s. A big shift, however, was that adult children affected wealth much more negatively in the 1900s. At that time they had a negative impact on wealth for skilled workers, and no significant impact for the unskilled, indicating that the former had enough economic resources to be able to prioritize education for their children, while such sacrifices normally were beyond the horizon for unskilled workers. The conclusion is that net costs for children had increased during the nineteenth century and that having children had become a considerably more expensive solution to secure support in old age. The results lead to two further reflections. Firstly, there obviously were rather strong economic incentives for family planning at the turn of the twentieth century, which is in accordance with the fact that fertility fell at the end of the nineteenth century. Secondly, there appears to have been a transformation in the meaning of economic dependence on children during the nineteenth century. Hence, when analyzing effects on the living 
standards of families, it seems to be of utmost importance to consider not only children's contributions to family income, but also the costs for raising children.

Old workers who were probated had nearly four times as much wealth in the 1900s as in the 1820s. This, however, does not mean that life cycle saving was established among Swedish workers at the later date. Only a minority had wealth enough for maintenance at a subsistence level during more than a couple of years, and very few had enough wealth for full retirement in old age. For most workers, net wealth was rather small and could only function as a buffer against loss of income during shorter periods. More old workers had such a buffer in the 1900s than in the 1820s, which probably meant somewhat greater freedom of action, but an overwhelming majority still had to rely on their own ability to work or on some form of support, for example poor relief, or help from children and other relatives.

In the 1820s real estate was an important element in providing for old age. Having children facilitated this, probably by making it easier to pay off debts. Few workers owned real estate in the 1900s. On the other hand, financial assets, totally missing in the $1820 \mathrm{~s}$, were of rather great importance at the turn of the twentieth century. Their prominence increased further during the first decades of the century, as endowment assurances became very popular among workers. As such assets were liquid, they were especially convenient for maintenance during old age. Workers with many children had considerably less financial assets (including endowments) than those without children. This leads to the conclusion that at this time an older way of providing for old age (dependence on children) impeded a new way for this purpose, financial saving. This conflict, between an older and a more modern way to privately provide for old age, seems to be a factor that deserves more attention in analyses of the underlying causes for public pensions.

\section{Acknowledgements}

The authors would like to thank the participants at the ESSHC session 'Women, Family Income and Expenditures in the nineteenth and early twentieth Century', held in Glasgow in April 2012, as well as Lynn Karlsson, and two anonymous referees, for valuable comments and suggestions on earlier drafts of this article. The authors also acknowledge financial support from the Jan Wallander and Tom Hedelius' Foundation, Sweden, for the project 'Family saving in a life cycle perspective'.

\section{Notes}

1. The Swedish guild system was abolished in 1846. Magnusson, 2010, pp. 237-8.

2. In fact this means that individuals with probated wealth over 4500 SEK or net debts over 1750 SEK were excluded in the 1820s. For the 1900s corresponding limits were 10,000 SEK and 2000 SEK respectively. Wealth in constant prices 1900-04 (Jörberg, 1972, p. 350).

3. Riksdaler riksgälds was the official currency in the 1820s and the Swedish Krona (SEK) became the official currency from 1873. Edvinsson (2010, p. 47).

4. During the first half of the nineteenth century children often started factory work at the age of 10. Olsson (1980, pp. 80-5).

5. Edgren (1982, pp. 27-43) draws a similar conclusion regarding master artisans' ability to save for retirement.

6. The average daily wage for an unskilled worker in Stockholm in 1820-25 was 0.68 riksdaler riksgälds. www.Historia.se. The amount has been calculated by using 300 working days per year.

7. Out of a total of 54 workers, 21 (39\%) had more wealth than the yearly earnings for an unskilled worker. The probate rate was $30 \%$.

8. For workers older than 60 years, the correlation between having children and owning real estate was $r=0.41(p=0.009)$.

9. Haines (1979). For mine workers in Sweden, Lilja (2004), pp. 160-162 shows that this happened when they were in their 40s. 
10. Average annual earnings were 947 SEK. Bagge et al. (1933, p. 260).

11. To test if the difference between $1820-25$ and $1900-05$ was significant, the two groups, master artisans and workers, in 1820-25 (skilled workers and unskilled workers 1900-05) were added together because there were so few observations. This test resulted in $\mathrm{chi}^{2}=4.24$ and $p=0.039$. In the comparison no consideration was taken to changes in the norm for poor relief, as data for this were lacking for the $1820 \mathrm{~s}$.

12. In 1901-1910 expectation of life at the age of 65 was 13 years, and in 1820 it was 10 years. Historical statistics... (1969).

13. $29 \%$ had poor relief. $12 \%$ got private support as well as poor relief. Ålderdomsförsäkringskommittén. IV. Statistiska utredningar (1912), pp. 603-25 and 770.

14. For a different interpretation, see Szreter (1996).

15. For a 15 year old person, life expectancy was 49.8 years (male) and 51.5 years (female). Historical statistics for Sweden ... (1969).

16. In fact median age at death was approximately 65 for the probated in 1900-05 with adult children.

17. For skilled workers the correlation between the number of children and the amount of financial assets was $r=-0.28(p=0.004)$. For unskilled workers corresponding figures were $r=-0.17(p=0.012)$.

18. For those in the lowest income quartile the difference was $23 \%$, and for those in the highest it was $7 \%$. Sveriges officiella statistik (SOS) (1921b).

\section{Archive material}

\section{Landsarkivet in Uppsala (ULA) (Provincial records office in Uppsala)}

Eskilstuna Rådhusrätt och magistrat. Bouppteckningar [Probate inventories], FII, Vol. 14-15, 1820-25; Eskilstuna, Klosters och Fors församlingar, Husförhörslängder [Parish catechetical meeting records], Aib, Vol. 7-8, and Vigsel-, födsel- och dödslängder [Marriage, birth, and death records] för Eskilstuna: Gamla staden, Nya staden, Carl-Gustafs församling ('Stadsförsamlingen') and Gredby, Fors socken, C: 6-7, 1819-25; Husförhörslängder för Eskilstuna Fristaden [Parish catechetical meeting records], A1c, Vol. 8-9, 1820-24.

Falu Rådhusrätt och magistrat. Bouppteckningar och arvskiften [Probate inventories and distribution of estates], FII 35-37, 1820-25; Falu Kristine församling. Död- och begravningsböcker [Death and burial records], F3, 1819-25; Stora Kopparbergs församling. Död- och begravningsböcker [Death and burial records], F1, 1819-25.

Uppsala Rådhusrätt och magistrat. Bouppteckningar [Probate inventories], FIIa, Vol. 38-44, 182025; Uppsala Domkyrkoförsamling. Död- och begravningsböcker [Death and burial records], Fa, Vol. 4, 1819-25.

Rådhusrättens och magistratens i Eskilstuna arkiv. Bouppteckningar [Probate inventories], FII, Vol. 31-36, 1900-05; Eskilstuna, Kloster och Fors församlingar, Död- och begravningsböcker [Death and burial records], F3; 1900-02.

Falu rådhusrätt och magistrat. Bouppteckningar och arvskifte [Probate inventories and distribution of estates], FI, Vol. 65-67, 1900-05; Falu Kristine församling. Död- och begravningsbok [Death and burial records], FI, Vol. 9, 1900-02.

Uppsala Rådhusrätt och magistrat. Bouppteckningar [Probate inventories], FIIa, Vol. 80,1900, FII, Vol. 25-9, 1901-05; Uppsala domkyrkoförsamling, serie för död- och begravningsböcker [Death and burial records], F, Vol. 1, 1900-01, and F:s, 1902.

\section{References}

Allen, R. C. (2001). The great divergence in European wages and prices from the middle ages to the first world war. Explorations in Economic History, 38, 411-447.

Alter, G. (1996). The European marriage pattern as solution and problem: Households of the elderly in Verviers, Belgium, 1831. The History of the Family, 1, 123-138.

Bagge, G., Lundberg, E., \& Svennilson, I. (1933). Wages, cost of living and national income in Sweden 1860-1930, Vol. II. Wages in Sweden 1860-1930. London: P.S. King and son, Ltd. 
Barnes, G. A., \& Guinnane, T. W. (2012). Social class and the fertility transition: A critical comment on the statistical results reported in Simon Szreter's fertility, class and gender in Britain, 18601940. The Economic History Review, 65, 1267-1279.

Becker, G. S. (1993). A treatise on the family. Cambridge, MA: Harvard UP.

Bengtsson, T. (2006). Den demografiska transitionen och samhällsomvandlingen [The demographic transition and the transformation of society]. In S. Hedenborg \& M. Morell (Eds.), Sverige - en social och ekonomisk historia [Sweden - a social and economic history]. Lund: Studentlitteratur.

Bergander, B. (1967). Försäkringsväsendet i Sverige 1814-1914. [The insurance market in Sweden 1814-1914]. Stockholm: Eget förlag.

BiSOS (Bidrag till Sveriges officiella statistik) A, Befolkningsstatistik 1900. Del 3. [Contributions to Sweden's official statistics: Population statistics 1900]. (1903). Stockholm: P.A. Norstedt \& Söner.

BiSOS (Bidrag till Sveriges Officiella Statistik) C, Bergshandtering 1900. [Contributions to Sweden's official statistics: Mining 1900]. (1901). Stockholm: P.A. Norstedt \& Söner.

BiSOS (Bidrag till Sveriges Officiella Statistik) D, Fabriker och handtverk 1900. [Contributions to Sweden's official statistics: Manufacturing industries and handicrafts 1900]. (1902). Stockholm: P.A. Norstedt \& Söner.

BiSOS (Bidrag till Sveriges Officiella Statistik) F, Handel 1900. [Contributions to Sweden's official statistics: Trade 1900]. (1901). Stockholm: P.A. Norstedt \& Söner.

Boyer, G. R. (2009). Insecurity, safety nets, and self-help in Victorian and Edwardian Britain. In D. Eltis, et al. (Eds.), Human capital and institutions. A long run view (pp. 46-89). Cambridge, MA: Cambridge UP.

Bringéus, N.-A. (1977). Bouppteckningar som etnologisk källa. [Probate inventories as an ethnological source]. Lund: Småskrifter från Etnologiska sällskapet i Lund.

Bäcklund, D., \& Lilja, K. (2010). Children and the wealth of widowed. Paper at The European Social Science History Conference in Ghent; Belgium, 13-16 April.

DDB (Demographic Data Base), Tabellverket på nätet. Umeå: Umeå University. Folkmängden [Population] formulär 320. Online.

Di Matteo, L. D. (1997). The determinants of the wealth and asset holding in nineteenth-century Canada: Evidence from microdata. The Journal of Economic History, 57, 907-934.

Early, F. H. (1982). The French-Canadian family economy and standard-of-living in Lowell, Massachusetts, 1870. Journal of Family History, Summer 1982 7, 180-199.

Easterlin, R. A. (1998). Growth triumphant. The twenty-first century in historical perspective. Ann Arbor: The University of Michigan Press.

Edgren, L. (1982). Hantverk och åldrande: hantverkets äldre män och kvinnor i Malmö 1820. [Craftsmanship and ageing: Old men and women in the town of Malmö in 1820]. Uppsala: Uppsala University.

Edgren, L. (1987). Lärling, gesäll, mästare. Hantverk och hantverkare i Malmö 1750-1847. [Apprentice, journeyman, master. Crafts and craftsmen in Malmö 1750-1847]. Lund: Universitetsförlaget Dialogus.

Edvinsson, R. (2010). Swedish monetary standards in a historical perspective. In R. Edvinsson, T. Jacobson, \& D. Waldenström (Eds.), Exchange rates, prices, and wages, 1277-2008 (pp. 26-66). Stockholm: Sveriges Riksbank, Ekerlids förlag.

Elmér, Å. (1960). Folkpensioneringen i Sverige. [Retirement pension scheme in Sweden]. Lund: Gleerup.

Galasso, V., Gatti, R., \& Profeta, P. (2009). Investing for the old age: Pensions, children and savings. International Tax Public Finance, 16, 538-559.

Haines, M. R. (1979). Industrial work and the family life cycle, 1889-1890. Research in Economic History, 4, 289-356.

Haines, M. R. (1985). The life cycle, savings and demographic adaptation: Some historical evidence for the United States and Europe. In A. S. Rossi (Ed.), Gender and the life course. New York, NY: Aldine.

Historical statistics of Sweden, part 1. Population, second edition. 1720-1967. (1969) Stockholm: National Central Bureau of Statistics.

Högman, A.-K. (1999). Ageing in a changing society. Elderly men and women in urban Sweden 1830-1930. Umeå: Umeå University. 
Hörsell, A. (1983). Borgare, smeder och änkor. Ekonomi och befolkning i Eskilstuna gamla stad och Fristad 1750-1850. [Burgers, smiths, and widows. Economy and population in Eskilstuna old town and free city 1750-1850]. Uppsala: Uppsala University.

Isacson, M. (1979). Ekonomisk tillväxt och social differentiering 1680-1860. Bondeklassen i By socken, Kopparbergs län. [Economic development and social differentiation 1680-1860. The peasant class in a Parish in Dalecarlia]. Uppsala: Uppsala University.

Isacson, M., \& Magnusson, L. (1987). Proto-industrialisation in Scandinavia. Craft skills in the industrial revolution. Leamington Spa/Hamburg/New York: Berg.

Jellal, M., \& Wolff, F.-C. (2002). Insecure old-age security. Oxford Economic Papers, 54, 636-648.

Johnson, P. (1984). Self-help versus state help: Old age pensions and personal savings in Great Britain, 1906-1937. Explorations in Economic History, 21, 329-350.

Johnson, P. (1985). Saving and spending. Oxford: Clarendon Press.

Jörberg, L. (1972). A History of prices in Sweden 1732-1914, vol. II. Lund: Gleerup.

Lilja, K. (2004). Marknad och hushåll. Sparande och krediter i Falun 1820-1910 utifrån ett livscykelperspektiv. [Market and household. A study of savings and credit on the local credit market in the town of Falun 1820-1910]. Uppsala: Uppsala University.

Lilja, K. (2009). Working-class saving in the nineteenth and early twenty century Sweden. Paper presented at The XVth World Economic History Congress in Utrecht.

Lilja, K. (2010). The deposit market revolution in Sweden. In A. Ögren (Ed.), The Swedish financial revolution. Basingstoke and New York: Palgrave Macmillan.

Lundh, H. (1977). Uppsala stads historia IV. [The history of the town of Uppsala IV]. Uppsala: Historiekomm.

Magnusson, L. (1988). Den bråkiga kulturen. [The unruly culture]. Stockholm: Författarförlaget.

Magnusson, L. (2010). Sveriges ekonomiska historia. [An economic history of Sweden]. Stockholm: Norstedts.

Modigliani, A., \& Brumberg, R. (1954:1980). Utility analysis and the consumption function. In A. Abel (Ed.), The collected papers of Franco Modigliani. vol. 2. Cambridge, MA: MIT P.

Montelius, S. (1993). Västerås genom tiderna. Del III. [The town of Västerås during the ages. Part $I I I]$. Västerås: Västerås stad.

Montgomery, A. (1951). Svensk socialpolitik under 1800-talet. [Swedish social policy during the 19th century]. Stockholm: KF:s bokförlag.

Moring, B. (2007). The standard of living of widows: Inventories as an indicator of the economic situation of widows. The History of the Family, 12, 233-249.

Moring, B. (2008). Widows, children and assistance from society in urban Northern Europe 18901910. The History of the Family, 13, 105-117.

Myrdal, G. (1933). Wages, cost of living and national income in Sweden 1860-1930, Vol. I. The cost of living in Sweden 1830-1930. London: P.S. King and son, Ltd.

Nilsson, A., \& Pettersson, L. (1993). Utbildning, ekonomisk omvandling och tillväxt. [Education, economic tranformation and growth]. Äventyret Sverige. [The Swedish adventure]. Stockholm: UR \& Bra böcker.

Nilsson, L. (1989). Den urbana transitionen. [The urban transition]. Stockholm: Stadshistoriska institutet.

Nilsson, L. (1992). Historisk tätortsstatistik. Del 1. Folkmängden i administrativa tätorter 18001870. [Historical statistics of population centres. Part 1. Population in administrative population centres]. Stockholm: Stads- och kommunhistoriska institutet.

Ohlsson, B.-E. (2001). Från hantverk till industri, (From handicraft to manufacturing industry). In B.-E. Ohlsson, E. Ericsson, \& U. Magnusson (Eds.), Eskilstuna historia. 1800-talet och 1900talet. [The history of the town of Eskilstuna. The 19th and the 20th centuries] (pp. 9-49). Eskilstuna: Stadsarkivet.

Olsson, L. (1980). Då barn var lönsamma. [When children were profitable]. Stockholm: Tidens förlag.

Olsson, U. (1986). Recent research in Sweden on the standard of living during the eighteenth and nineteenth centuries. Scandinavian Economic History Review, 34, 153-158.

O'Rourke, K. H., \& Williamson, J. G. (1995). Open economy forces and late nineteenth century Swedish catch-up. A quantitative accounting. Scandinavian Economic History Review, 43, $171-203$.

Pérez-Fuentes Hernández, P., \& Pareja Alonso, A. (1997). Ageing alone or in a family: The case of Bilbao, 1825-1935. Continuity and Change, 12, 79-102. 
Robinson, R. V. (1995). Family economic strategies in nineteenth-and early twentieth-century Indianapolis. Journal of Family History, 20(1), 1-22.

Schön, L. (2000). En modern svensk ekonomisk historia. [A modern economic history of Sweden]. Stockholm: SNS förlag.

Söderberg, J. (2010). Long-term trends in real wages of labourers. In R. Edvinsson, T. Jacobson, \& D. Waldenström (Eds.), Exchange rates, prices, and wages, 1277-2008. Stockholm: Sveriges Riksbank, Ekerlids förlag.

SOS (Sveriges officiella statistik), Folkräkningarna 1910. III. [Sweden's official statistics. Census of population 1910. III]. (1917). Stockholm: P. A. Norstedt \& söner.

SOS (Sveriges officiella statistik), Levnadskostnaderna i Sverige 1913-1914. Del I. Utredningens huvudresultat. [Sweden's official statistics. The cost of living in Sweden 1913-1914. Part I. Main results]. (1921a). Stockholm: Socialstyrelsen.

SOS (Sveriges officiella statistik). Levnadskostnaderna $i$ Sverige 1913-1914 Del III. Hushållsräkenskaper. [Sweden's official statistics. The cost of living in Sweden 1913-1914. Part III. Domestic accounts]. (1921b). Stockholm: Socialstyrelsen.

Sveriges nationalförmögenhet omkring år 1908 och dess utveckling sedan midten av 1880-talet. [Sweden's national wealth around 1908 and its development since the mid-1880s]. (1912). Stockholm: Finansdep.

Szreter, S. (1996). Fertility, class and gender in Britain, 1860-1940. Cambridge, MA: Cambridge UP.

Ullenhag, K. (1984). Industriell utveckling och demokratisering 1862-1921, Uppsala stads historia V. [Industrial development and democratization 1862-1921. The history of the town of Uppsala V]. Uppsala: Almqvist \& Wiksell.

Wall, R. (2010). Economic collaboration of family members within and beyond households in English society, 1600-2000. Continuity and Change, 25, 83-108.

Ålderdomsförsäkringskommittén. IV. Statistiska utredningar. [Old-age insurance committee. IV. Statistical investigation]. (1912) Stockholm: Ålderdomsförsäkringskommittén.

\section{Appendix 1}

Table A1. Workers 1820-25 (including estimated age). Determinants of assets and debts (Dependent variable: Square roots of assets/debts in riksdaler riksgälds).

\begin{tabular}{|c|c|c|c|c|}
\hline \multirow{2}{*}{ Variable } & \multicolumn{2}{|c|}{ Assets } & \multicolumn{2}{|c|}{ Debts } \\
\hline & Coeff. & $\mathrm{T}$ & Coeff. & $\mathrm{T}$ \\
\hline Constant & 3.36 & 0.42 & 6.59 & 1.08 \\
\hline Age & 0.38 & 1.10 & -0.17 & -0.64 \\
\hline $\mathrm{Age}^{2}$ & -0.0031 & -0.91 & 0.0014 & 0.56 \\
\hline Male & 2.02 & 1.17 & 1.11 & 0.86 \\
\hline Married & $-5.68 * *$ & -2.37 & -1.03 & -0.57 \\
\hline Widowed & 0.31 & 0.14 & 0.85 & 0.52 \\
\hline Eskilstuna & 0.79 & 0.27 & 2.43 & 1.09 \\
\hline Falun & 2.33 & 1.43 & 0.89 & 0.72 \\
\hline$\sqrt{ } \operatorname{ch} 0-10$ & 0.07 & 0.04 & $2.95 * *$ & 2.15 \\
\hline$\sqrt{ } \operatorname{ch} 11-20$ & 1.52 & 0.95 & $3.49 * * *$ & 2.89 \\
\hline$\sqrt{ } \operatorname{ch} 21-$ & $2.58 *$ & 1.88 & 1.16 & 1.12 \\
\hline $\mathrm{N}$ & \multicolumn{2}{|c|}{129} & \multicolumn{2}{|c|}{129} \\
\hline $\mathrm{R}^{2}$ & \multicolumn{2}{|c|}{0.13} & \multicolumn{2}{|c|}{0.15} \\
\hline $\mathrm{F}$ & \multicolumn{2}{|c|}{1.73} & \multicolumn{2}{|c|}{2.07} \\
\hline
\end{tabular}

Note: $* p<0.10, * * p<0.05, * * * p<0.01$. Sources: See Table 3. Note: $\sqrt{ }$ ch0-10, $\sqrt{ }$ ch $11-20$, and $\sqrt{ } \operatorname{ch} 21-=$ square roots of the number of children aged $0-10$ years, 11-20 years, and 21 years and older, respectively. 